\title{
Hamas: The Fighter of the Holy City of Jerusalem (Malay Version)
}

Iqbal $\mathbf{U}^{*}$

History Programme, Faculty of Social Sciences and Humanities, National University of Malaysia, Malaysia

"Corresponding author: Iqbal U, History Programme, Faculty of Social Sciences and Humanities, National University of Malaysia, UKM 43650, Bangi Selangor, Malaysia, Tel: 60389215555; E-mail: uqbah@siswa.ukm.edu.my

Received date: April 25, 2016; Accepted date: April 26, 2016; Published date: April 28, 2016

Citation: Iqbal U (2016) Hamas: The Fighter of the Holy City of Jerusalem (Malay Version). Arts Social Sci J 7: 175. doi:10.4172/2151-6200.1000175

Copyright: (c) 2016 Iqbal U. This is an open-access article distributed under the terms of the Creative Commons Attribution License, which permits unrestricted use, distribution, and reproduction in any medium, provided the original author and source are credited.

\section{Opinion}

Since the Palestinians elected them in 2006 election, Hamas prove that they protect the Palestinian people. This book tries to show one day in the future, people will definitely remember the history, there is a group of terrorists called Zionists and Israel as their country is God's most violent and brutal creature in the world. History will also remember that there are a group of sincere people who strove for independence beat the Zionist terrorist that is Hamas. The book begins with an order from Dr. Khalil Ismail al-Hayya representing Hamas in Palestine for Muslims in Malaysia.

Hamas does not appear abruptly. It appearance is not due to the frustration of some people in Fatah. Hamas is not a movement that is created by the Likud to disrupt Palestinian society. Hamas stressed that their struggle back to Syeikh Izzuddin al-Qassam fight during Palestinian Revolutionary 1936. Hamas struggle as described in the constitution are coming out from the Muslim Brotherhood movement. This movement founded in Egypt as early as 1928.

The political thought and ideology of Hamas is focused on a number of policies which Hamas is a national organization that is based on Islam and make jihad as a principle, Hamas believes liberation of Palestine efforts will not be successful without the participation of the Muslim world and the Arabs as a whole, Hamas believes that the Palestinian issue is the issue of Muslims and liberation of Palestine efforts are the responsibility that must be shouldered by all Muslims wherever they are, Hamas believes that war with the Israel Zionist regime is a war of civilizations that is rooted in the faith of Islam, Hamas believe the Zionist project of the state of Israel is something that is planned by the West as it is to their advantage in terms of strategy, economic, hegemony, cultural and religious, Hamas believes that war with the Zionists is a battle for life and not just grab a state, Hamas reiterated their opposition to the Zionists and the Jews who were with them not because they were Jews and religious Jews, Hamas adhered to the principle only jihad most effective way to liberate Palestine, Hamas stressed that the Palestinian people are the front line of Muslims in resisting the Zionist project worldwide, Hamas strives to maintain identity as a national movement fighting for independence based on the principle Islam, Hamas remains committed to their holding that Palestin is the homeland of Muslims until the day of Judgment, Hamas respect the principles of political freedom, pluralization and also differences of opinion and Hamas recognize the right of religious freedom.

Hamas's strategic objectives can be summarized into two fundamental things namely liberate the whole of Palestine from the River Jordan to the Mediterranean Sea and establishing a Palestinian state based on Islamic principles. Hamas has always respected each faction that exists in Palestine, which has always fought for independence such as the Palestine Liberation Organization, Fatah Movement and Islamic Jihad. Hamas is not an organization that depends on the individual popularity. Reality show after the assassination of two leaders of Hamas, Abdul Aziz Rantisi and Syeikh Ahmed Yassin, Hamas' popularity is surging.

The author also discussed the articles produced by authors from Malaysia regarding Hamas in the English-speaking media. It is considered boring because like a repeat of what has been written by the West and then added with a taste of Malaysia. Most writers cannot access Arabic references which is the main source of information regarding Hamas. Most of them rely on what was said by the West who is mostly pro-Zionist or even anti-Islamic. As a result, most of them discriminate Hamas and terrorizing their struggle. Most of the accusations hurled at Hamas solely based on what the other person said without notice and follow its own development. When the West suspicious of Hamas, Malaysian authors also translate it into local media. When the West said Hamas militants, they also repeat it, that kind of thing so they forget about the real issue.

The book also contains an interview with the Hamas Christian Minister, namely Ir. Jawdat Marcus as the Minister of Tourism and History after the new Palestinian Hamas-led cabinet was announced. This book also includes biographical of Hamas figures, namely Syeikh Ahmad Yassin, Dr. Abdul Aziz al-Rantissi, Khalid Mesh'al, Mahmoud Zahhar, Ismail Haneyyah, Syeikh Salah Syahada, Ibrahim Maqadmah, Jamal Mansour, Ismail Abu Shanab and Yahya Ayyash. Also included the views of individuals from Israel about Hamas, namely General Ori Saghi, Chief of the Shin Bet, the analysts of the Zionist regime, Yaacov Jevri, Head of the Shabak, Ami Iyalon, former head of Shabak, Danny Rothschild, Head of the Mossad Department of Strategic Studies, Shimon Romanh, one of the leaders of the Shabak, Tsefi Yulin, IDF general, Karmi Gelon, former Shabak chief and Alistair Crooke, a former MI-6 Liaison Officer in Middle East affairs related to Islamic movements. Hamas important dates also included in this book that started from 1984 until January 25, 2006. Before Hamas, there are many struggle variations try their luck. Based on the ideology of various and multifarious creed, all failed. Whether failure due losing the fight or lost because they could not continue the fight. There are among those who were forced to mortgage principles and have had to change course. Such things do not happen to Hamas. Starting with the First Intifada in 1987 and then to the Second Intifada in 2000 and the peak of their victory in the 2006 election showed Hamas had a secret to maintain their momentum. 